\title{
PENGARUH MODEL KEPEMIMPINAN KEPALA MADRASAH TERHADAP PENINGKATAN KINERJA DAN DISIPLIN GURU
}

\author{
St. Muthahharah ${ }^{1}$ \\ Pendidikan Agama Islam Fakultas Agama Islam| Unismuh Makassar
}

\begin{abstract}
ABSTRAK
Tujuan penelitian ini adalah untuk menemukan dan menganalisis pengaruh Model Kepemimpinan Kepala Madrasah terhadap peningkatan Kinerja dan Disiplin Guru. Jenis penelitian yang digunakan bersifat deskriftif kuantitatif, yang beralokasi di Kelurahan Ereng-Ereng Kecamatan Tompobulu Kabupaten Bantaeng. Teknik pengambilan sampel yaitu sampel jenuh sebanyak 20 subjek. Teknik pengumpulan data melalui observasi, koesioner, interview, dan dokumentasi. Analisis data dengan langkah-langkah berupa validitas, realibilitas, uji normalitas, linearitas dan uji hipotesis dengan menggunakan rumus regresi linier sederhana dengan SPSS 17 for Windows.Berdasarkan hasil analisis data yang dilakukan, maka nilai signifikansi yang diperoleh 0,000 , sedangkan nilai resquare menunjukkan 0,53 artinya terdapatpengaruh model kepemimpinan kepala madrasah terhadap peningkatan kinerja dan disiplin guru di Madrasah Aliyah Pondok Pesantren KH. Ahmad Dahlan Muhammadiyah Ereng-Ereng Kabupaten Bantaeng sebesar 53\%. Adapun $47 \%$ kinerja dan disiplin guru dipengaruhi oleh faktor-faktor yang lain.
\end{abstract}

\section{Kata kunci: Model Kepemimpinan, Kepala Madrsah, Kinerja dan Disiplin Guru}

\begin{abstract}
The purpose of this study is to find and analyze the effect Principals Leadership Model to increase performance and Discipline Teachers). This type of research is descriptive quantitative, which is located in Ereng-ereng District of Tompobulu Bantaeng. Sampling technique that saturated sample of 20 subjects. Technique of collecting data through observation, questioner, interview, and documentation. Analysis of data by measures such as validity, reliability, test for normality, linearity and hypothesis testing using simple linear regression formula with SPSS 17 for Windows. Based the results of the data analysis, the significant value gained 0,000, while the value of $r$ square shows 0,53 means that ifluence headmaster leadership model to the improved performance and discipline of teachers in Madrasah Aliyah boarding school KH. Ahmad Dahlan Muhammadiyah Ereng-ereng, Bantaeng by 53\%. As for the 47\% performance and teachers discipline inflenced by other factors.
\end{abstract}

Keywords: Leadership Model, Head Master of Madrasah, Work Performance and Teachers Discipline. 


\section{PENDAHULUAN}

Kepala madrasah sebagai pemimpin profesional di lembaga pendidikan mempunyai peran yang sangat penting, mengingat posisinya yang secara struktural sebagai pimpinan legal formal memiliki kekuasaan penuh pada lembaga yang dipimpinnya. Perangkat sekolah seperti kepala madrasah, dewan guru, siswa, pegawai/ karyawan harus saling mendukung untuk dapat bekerja sama mencapai tujuan yang telah ditetapkan. Oleh karena itu dapat dikatakan bahwa sukses atau tidaknya suatu organisasi mencapai tujuan yang telah ditentukan sangat tergantung atas kemampuan pimpinannya untuk menumbuhkan iklim kerja sama agar dengan mudah dapat menggerakkan sumber daya manusia yang ada, sehingga pendayagunaannya dapat berjalan dengan efektif dan efisien.

Lembaga pendidikan, baik itu sekolah atau madrasah dibutuhkan kepala madrasah profesional, dan juga perlu adanya tenaga kependidikan yang kompeten dan profesional. Hal ini dikarenakan pencapaian tujuan pendidikan sangat tergantung pada kualitas tenaga pendidik, dalam hal ini guru, karena memegang peran sentral dalam proses pembelajaran, yang harus berinteraksi langsung dengan para peserta didik di sekolah/ madrasah.

Kredibilitas dan kinerja yang baik tersebut ditentukan oleh beberapa pihak baik kinerja pendidik maupun tenaga kependidikan dalam melaksanakan tugas-tugasnya. Hal ini didukung pendapat Prawirosentoso bahwa "kinerja merupakan hasil kerja yang dapat dicapai oleh seseorang atau sekelompok orang dalam suatu organisasi, sesuai dengan wewenang dan tanggung jawab masing-masing". Hal yang sama dikatakan oleh Mangkunegara yang mendefinisikan "kinerja adalah hasil kerja secara kualitas dan kuantitas yang dicapai seorang karyawan dalam melaksanakan tugasnya sesuai dengan tanggung jawab yang diberikan kepadanya".

Salah satu faktor yang mempengaruhi kinerja dan disiplin guru adalah kepala madrasah. Kepala madrasah merupakan pimpinan tertinggi dalam lembaga pendidikan madrasah. Perilaku kepemimpinannya sangat berpengaruh bahkan sangat menentukan kinerja guru. Oleh karena itu dalam pendidikan modern, kemampuan manajerial kepala madrasah perlu mendapatkan perhatian yang serius. Hal ini penting untuk diperhatikan agar kepala madrasah dapat berperan dengan baik dalam mencapai tujuan madrasah yang telah direncanakan.

Keberhasilan madrasah sangat ditentukan oleh kemampuan kepala madrasah dalam memimpin organisasi sekolah, karena kepala madrasah merupakan pengendali dan penentu arah yang hendak ditempuh oleh madrasah menuju tujuannya. Dengan demikian kepala madrasah mempunyai peranan besar dalam meningkatkan kualitas guru dan harus terus menerus membina moral kerja guru, sehingga setiap guru akan melaksanakan tugas dengan sebaik-baiknya. Pencapaian tujuan sekolah baik secara kuantitas maupun kualitas tidak terlepas dari orang-orang yang tergabung dalam organisasi sekolah/ madrasah.

Kinerja guru di madrasah tidak hanya dipengaruhi oleh pelaksanaan tugas dan pekerjaannya termasuk seberapa besar kewenangan dan 
tanggung jawabnya, tetapi ditentukan juga antara lain oleh faktor kepemimpinan kepala madrasah dan budaya organisasi yang berlaku dan berjalan di madrasah tersebut.

Sikap disiplin yang ditunjukkan oleh guru menunjukkan salah satu bentuk kinerja guru. Ukuran kinerja guru terlihat dari rasa tanggung jawabnya menjalankan amanah, profesi, yang diembannya, rasa tanggungjawab moral yang diembannya. Semua itu akan terlihat dari kepatuhan dan loyalitas di dalam menjalankan tugas keguruannya di dalam kelas dan tugas kependidikannya di luar kelas.

Pokok permasalahan dalam penelitian ini adalah: bagaimana model kepemipinan kepala madrsah di Madrasah Aliyah Pondok Pesantren KH. Ahmad Dahlan Muhammadiyah Ereng-Ereng Kabupaten Bantaeng?, bagaimana gambaran tingkat kinerja dan disiplin guru di Madrasah Aliyah Pondok Pesantren KH. Ahmad Dahlan Muhammadiyah Ereng-Ereng Kabupaten Bantaeng?, Apakah model kepemimpinan kepala madrsah berpengaruh terhadappeningkatan kinerja dan disiplin guru di Madrasah Aliyah Pondok Pesantren KH. Ahmad Dahlan Muhammadiyah Ereng-Ereng Kabupaten Bantaeng?

\section{METODE PENELITIAN}

Jenis penelitian yang digunakan bersifat deskriftif kuantitatif, untuk mengungkapkan fakta yang berkaitandengan pengaruh model kepemimpinan terhadap tingkat kinerja dan disiplin guru pada objek penelitian.

Lokasi penelitian adalah di Madrasah Aliyah Pondok Pesantren
KH. Ahmad Dahlan Muhammadiyah Ereng-Ereng Kabupaten Bantaeng. Populasi dalam penelitian ini adalah seluruh guru, kepala sekolah, dan stafpada objek penelitian. Sampel dalam penelitian ini diambil dari seluruh populasi yang ada dengan teknik pengambilan sampling jenuh yaitu teknik penentuan sampel bila semua anggota populasi digunakan sebagai sampel terdapat 20 subjek.

Teknikpengumpulan data yang digunakan oleh peneliti adalah dengan menyebarkan skala/angket, observasi, wawancara, dan dokumentasi. Untuk menganalisis data yang dikumpulkan setiap variabel digunakan analisis statistik deskriptip untuk menjawab pokok masalah pertama dan kedua, dan analisis statistik dengan menggunakan rumus regresi linier sederhana (dengan bantuanprogram statistik SPSS 17for windows)untuk menjawab pokok masalah ketiga.

\section{HASIL DAN PEMBAHASAN}

Berdasarkan kategorisasi bahwa tidak terdapat sebuah subjek $(0 \%)$ yang memiliki tingkat skor cukup, terdapat subjek (15\%) menyatakan kepemimpinan kepala madrasah baik, dan (85\%) menyatakan kepmimpian kepala madrasah sangat baik.Hasil interpertasi dan kategorisasi skor kepemimpian tersebut, dengan model kepemimpinan sangat baik sebanyak $85 \%$, dapat diperkuat dengan hasil wawancara bersama Hasriani (Guru Bahasa Indonesia), mengemukakan bahwa:

Pada dasarnya bapak kepala sekolah dalam memimpin madrasah sangat baik karena dan jika dilihat tipe kepemimpinan yang diterapkan oleh kepala 
madrasah dapat disimpulkan adalah tipe kepemimpinan demokratis. Hal ini disebabkan hampir setiap keputusan, kebijakan yang akan dikeluarkan terkait untuk kepentingan seluruh warga sekolah dikomunikasikan melalui rapat/ musyawarah yang dihadiri oleh seluruh guru-guru yang ada. Setiap masalah yang dihadapi sekolah dibicarakan dan mencari solusi serta meminta masukan/ ide, saran demi kemajuan sekolah, selain itu kepala sekolah juga menunjukkan bagaimana dia selama ini membangun kemunikasi dan kerjasama yang baik kepada orang tua/wali siswa, masyarakat serta pemerintah tekait yang tentunya untuk pengembangan dan kemajuan sekolah yang dipimpinnya. sebagai guru saya memberikan apresiasi yang setinggi-tingginya kepada bapak kepala madrasah atas segala pengorbanan baik dari segi waktu ataupun materil demi untuk kemajuan sekolah (Wawancara, 10 September 2016).

Senada dengan hal tersebut sebagaimana juga hasil wawancara bersama St. Nur ati (Guru Akidah Akhlak) yang mengemukakan bahwa:

Kepala madrasah menggunakan model atau gaya kepemimpinan demoktratis hal ini dapat dilihat dari beberapa indikasi yang ditunjukkan selama memimpin madrasah seperti mendiskusikan setiap masalah yang dihadapi sekolah, meminta saran, masukan terkaiat dengan kebijakan akan diputuskan baik di dalam ataupu di luar rapat secara formil.
Meskipun cukup demokratis dalam menjalankan tugasnya sebagai pemimpin sekolah, kepala madrasah juga cukup tegas dalam mengambil keputusan dan menerapkan tata tertib sekolah sehingga jika ada warga sekolah yang melakukan pelanggaran maka kepala sekolah akan memberikan bimbingan, peringatan atau bahkan menskorsing untuk jenis pelanggaran guru/ siswa yang berat (Wawancara, 10 September 2016).

Pendapat serupa juga dikatakan oleh Haerul (Guru Sosiologi) bahwa:

Kepala madrsah telah menjalankan tugasnya sebagai pemimpin/leadher, manager, juga motivator kepada guru dan seluruh warga sekolah. gaya kepemimpinan yang digukan dalam menjalankan fungsinya sebagai seorang pemimpin selama ini adalah kepemimpinan demokratis ini dapat dilihat ketika akan memutuskan suatu kebijakan selalu melibatkan guru, selain itu juga terbuka untuk menirima masukan, saran, ide bahkan kritikan demi kemajuan madrasah (Wawancara, 10 September 2016).

Berdasarkan hasil wawancara tersebut dapat diketahui bahwa model kepemimpinan kepala madrasah yang diterpakan pada Madrasah Aliyah Pondok Pesantren KH Ahmad Dahlan Muhammadiyah Ereng-Ereng Bantaeng adalah kepemimpinan demokratis, dimana kepala sekolah sangat terbuka dalam hal menerima saran, ide-ide, kritikan serta 
melibatkan guru pada saat akan mengeluarkan suatu kebijakan melalui forum musyawarah ataupun pertemuan yang bersifat non formal. Selain itu kepala madrasah aktif dalam memberikan bimbingan, motivasi, arahan serta membangun komunikasi dan kerjasama yang baik kepada warga sekolah, stakeholder, dan pemerintah. Hal ini dilakukan untuk meningkatkan kualitas dan kuantitas sumber daya manusia yang ada, sehingga pendayagunaannya dapat berjalan secara efektif dan efisien. Berdasarkan hasil analisis data yang diperkuat dengan hasil wawancara yang lakukan bersama beberapa guru ditemukan bahwa selama memimpin sekolah kepala madrasah menerapkan model atau tipe kepemimpinan demokratis dimana setiap akan mengambil keputusan ataupun kebijakan senantiasa melibatkan guru serta cukup terbuka dalam menerima saran, ide masuka-masukan serta kritikan yang membangun demi pengembangan dan kemajuan sekolah.

Berdasarkan hasil analisis data melalui bantuan program SPSS, ditemukan gambaran deskriptif kinerja guru di Madrasah Aliyah Pondok Pesantren KH Ahmad Dahlan Muhammadiyah Ereng-Ereng Bantaeng dengan kategorisasi dan interpretasi diperoleh data bahwa tidak terdapat subjek $(0 \%)$ yang memiliki tingkat kinerja rendah, terdapat subjek dengan tingkat kinerja sedang dengan persentase $20 \%$, dan $80 \%$ yang memiliki tingkat kinerja sangat baik. Hal ini berarti berdasarkan skor tingkat kinerja pada objek penelitian dikategorikan sangat baik.

Selain hasil data tersebut, peeliti juwa mewawancarai beberapa guru terkait dengan kinerja guru pada lokasi penelitian, diantaranya:

Nur Ati (Guru Akidah Akhlak), mengemukakan bahwa:

Guru merupakan jabatan profesional sebagaimana hal ini tertuang dalam Undang-Undang SISDIKNAS tentang Guru dan Dosen, sebagai seorang guru yang berupaya untuk menjadi guru profesional seperti amanah Undang-Undang maka kinerja guru harus lebih ditingkatkan melalui kegiatan-kegiatan baik yang dilaksanakan oleh pemerintah maupun kerjasama antar sekolah. Sehingga semaksimal mungkin mengikuti kegiatan-kegiatan tersebut, selain itu juga melanjutkan pendidikan kejenjang yang lebih tinggi sesuai dengan kualifikasi pendidikan sebelumnya. Hal ini sangat membantu guru meningkatkan kinerjanya dalam menjalankan tugas dan tanggungjawabnya sebagai pendidik dan output yang diharapkan adalah meningkatnya kualitas peserta didik dari segi kognitif, psikomotorik dan afektifnya (Wawancara, 10 September 2016).

Sementara Haerul (Guru Sosiologi) menyatakan bahwa:

Salah satu upaya yang dilakukan untuk meningkatkan kinerja guru adalah dengan mengikuti kegiatan seperti pelatihan media pembelajaran, musyawarah guru mata pelajaran (MGMP) yang biasa dilakukan secara rutin dengan bekerja sama antar sekolah. dan tentunya mempersiapkan semua perangkat pembelajaran yang dibutuhkan 
sebelum mengajar. Teori-teori yang didapatkan pada saat pelatihan diterapkan dalam kelas sehingga suasana kelas semakin berdinamika dan tidak terkesan menoton dengan menggunakan metode dan media pembelajaran yang bervariasi, hal ini sangat membantu dalam mencapai tujuan pembelajaran dan peserta didikpun sangat antusias serta besemangat dalam mengikuti proses pembelajaran. Sedangkan sistem penilaian yang digunakan berdasarkan sistem penlaian yang telah ditetapkan (Wawancara, 10 September 2016).

Berdasarkan hasil analisis data melalui program SPSS windows 7 diketahui bahwa tingkat kinerja guru pada objek penelitian $80 \%$ hal ini menandakan kinerja guru pada tingkat baik karena pada umumnya guru telah menyiapkan secara administratif perangkat pembelajaran yang dibutuhkan dalam proses pembelajaran. Sedangkan secara aplikatif guru pun telah merealisasikannya di dalam kelas, hal ini diperkuat dari hasil wawancara baik dengan guru maupun bersama dengan kepala madarasah, seperti telah menggunakan strategi, metode, media pebelajaran sesuai dengan karakter dan tujuan materi yang sedang dibahas agar siswa atau peserta didik lebih cepat menyerap pelajaran dan terciptanya suasana belajar yang lebih edukatif, efektif dan efesien sehingga akan mempengaruhi motivasi belajar, prestasi akademik, serta kreatifitas siswa.

Gambaran deskriptif mengenai tingkat disiplin guru diperoleh dari respon atau jawaban subjek terhadap skala yang diberikan. Adapun deskripsi data tingkat disiplin guru dapat dilihat berdasarkan kategorisasi dan interpretasi diperoleh data bahwa tidak terdapat subjek $(0 \%)$ yang memiliki tingkat disiplin rendah, terdapat subjek dengan tingkat disiplin sedang dengan persentase $30 \%$, dan $70 \%$ yang memiliki tingkat disiplin tinggi. Hal ini berarti skor tingkat disiplin pada objek penelitian dikategorikan tinggi.

Terkait dengan hal tersebut di atas, tingkat didiplin guru yang terdapat pada objek penelitian dapat digambarkan sebagaimana hasil wawancara yang dilakukan bersama beberapa guru MA Pondok Pesantren KH. Ahmad Dahlan Muhammadiyah Ereng-Ereng berikut ini. Hasil wawancara bersama Haerul mengemukakan bahwa:

Sebagai seorang guru tentulah harus bisa dan siap menjadi teladan untuk siswa-siswanya, baik dari segi cara berpakaian, ketepatan waktu, serta kepatuhan terhadap tata tertib yang belaku untuk seluruh warga sekolah. maslah kedisiplinan ini memang harus ditanamkan dalam diri setiap guru, siswa melalui proses pembiasaan, dengan begitu akan tercipta lingkungan pendidikan yang afektif dan efesien. Yang tentunya dibawah pengawasan pimpinan atau kepaa sekolah (Wawancara, 10 September 2016).

Sedangkan $\quad$ wawancara
bersama M. Wahyuddin
menyatakan bahwa:
Secara umum guru-guru telah
berdisiplin dan
dipersentasekan sekitar $85 \%$ telah
disiplin, baik dari regi
pelaksanaan tugasnya dalam


proses pembelajaran di kelas maupun proses pembinaan kegiatan ekstrakulikuler siswa. Namun sebagian kecil masih ditemukannya guru yang belum datang ke sekolah tepat waktu, dan masih terdapatnya guru yang mengajar melewati jam pelajaran yang telah ditetapkan. Hal ini membuat kepala sekolah tidak henti-hentinya memberikan bimbingan kepada seluruh guru, memberikan SP (Surat Peringatan) kepada guru dan peserta didik yang indisiplin, atau bahkan akan mngeluarkan guru/siswa yang melakukan pelanggaran yang berat, seperti melakukan hal yang dapat mencederai nama baik almamater sekolah (Wawancara, 12 September 2016).

Berdasarkan hasil analisis deskriptif diketahui bahwa tingkat kedisiplinan guru di Madrasah Aliyah Pondok Pesantren KH Ahmad Dahlan Muhammadiyah Ereng-Ereng Bantaeng berada pada kategori tinggi yaitu $75 \%$. Hal ini diperkuat dengan hasil wawancara bersama guru dan kepala madrasah, dapat diihat bahwa pada umumnya guru melaksanakan tugas dalam proses pembelajaran sesuai dengan jadwal yang ada, keterlibatan dalam setiap kegiatan yang dilaksanakan sekolah baik yang berhubungan langsung dengan guru maupun kegiatan yang berkaitan dengan siswa, dari segi ferformance penting untuk diperhatikan oleh guru karena ini merupakan salah satu bagian yang akan diteladani oleh siswa selain bagaimana bersikap, bertingkahlaku, bergaul dengan sesama guru dan siswa.
Berdasarkan hasil analisis data yang dilakukan, maka nilai $\mathrm{F}$ 123,08, signifikansi 0,000 dan nilai $r$ square menunjukkan 0,53 artinya bahwa pengaruh model kepemimpinan kepala madarasah terhadap tingkat kinerja dan disiplin guru di Madrasah Aliyah Pondok Pesantren KH. Ahmad Dahlan Muhammadiyah

Kabupaten Bantaeng memiliki pengaruh 53\%. Adapun sisanya sebesar $47 \%$ kinerja dan disiplin guru dipengaruhi oleh faktor-faktor yang lain dan tidak menjadi objek kajian dalam penelitian ini.

Peningkatan kualitas sumber daya manusia merupakan sasaran utama dari pendidikan. Pendidikan dilaksanakan dengan usaha peningkatan pengetahuan, keterampilan, dan sikap, serta tingkah laku yang sesuai dengan nilai dan norma yang berlaku. Usaha itu di wujudkan melalui organisasi sekolah sebagai lembaga pendidikan formal. Dengan kata lain sekolah adalah tempat peningkatan kualitas sumber daya manusia, guru merupakan salah satu kunci berhasil tidaknya sebuah proses pendidikan dalam lembaga sekolah. Guru adalahseorang pendidik professional dengan tugas utama mendidik, mengajar, membimbing, mengarahkan, melatih, menilai dan mengevaluasi peserta didik.

Kinerja guru yang berkualitas ditentukan oleh banyak faktor, salah satunya adalah kemampuan manajerial kepala madrasah. Hal ini karena manajerial kepala madrasah adalah proses mendorong dan membantu orang lain untuk bekerja dengan antusias untuk mencapai tujuan.Oleh karena itu sebagai manajer maka kepala madrasah harus mampu menggerakkan para guru untuk 
mencapai kinerja yang maksimal melalui pemberian dorongan dan motivasi, atau dengan kata lain kepala madrasah harus mampu menjadi motivator yang handal. Selain akan meningkatkan kinerja guru, ketika kepala madrasah melaksanakan tugas dan fungsinya secara maksimal tentunya juga akan meningkatkan disiplin guru dalam menjalankan tanggung jawabnya sebagai pendidik profesional.

Menurut Yoesana (2013) bahwa faktor pendukung dominan bagikedisiplinan guru berasal dari dalam diriguru sendiri. Faktor-faktor tersebut yaitukompetensi profesional, motivasi, kreativitas, dan produktivitas guru, pendidikan,serta karakter guru. Bagi guruyang berdisiplin, karena sudah menyatu dalam dirinya, maka disiplin bukanlagi merupakan beban, namun sebaliknya membebani dirinya bila tidak berbuat disiplin. Nilai-nilai kepatuhan telah menjadi bagian dari perilaku kesehariannya.

Hasil penelitian ini menunjukkan bahwa kinerja guru di Madrasah Aliyah Pondok Pesantren KH. Ahmad Dahlan Muhammadiyah Ereng-Ereng Kabupaten Bantaeng 80 $\%$ yang memiliki tingkat kinerja sangat baik. Sedangkan tingkat disiplin gurunya berdasarkan hasil oleh data berada pada kategori tinggi yaitu $70 \%$. Meskipun tidak bisa dihindari masih ditemukannya beberapa kendalakendala, yang tentunya kendala tersebut telah diupayakan untuk ditangani oleh kepala sekolah sebagaimana hasil wawancara yang telah dikemukakan sebelumnya. Sementara tingkat pengaruh model kepemimpinan kepala madrasah terhadap tingkat kinerja dan disiplin guru pada objek penelitian sebesar
53\%, dan model/tipe kepemimpinan yang diterapkan kepala madrasah adalah dengan model kepemimpinan demokratis yang telah diterapkan oleh kepala sekolah dalam menjalankan tugas dan fungsinya sebagai pimpinan/manajer, dan motivator membantu guru dalam meningkatkan kualitas kinerja dan tingkat disiplinnya dalam menjalankan tugas keprofesionalannya.

\section{KESIMPULAN}

Hasil penelitian ini dapat ditarik beberapa kesimpulan sebagai berikut:

1. Berdasarkan kategorisasi didapatkan bahwa tidak terdapat subjek $(0 \%)$ yang memiliki tingkat skor cukup, terdapat subjek (15\%) menyatakan kepmimpinan kepala madrasah baik, dan (85\%) menyatakan kepemimpian kepala madrasah sangat baik dengan model atau tipe kepemimpinan yang diterapkan adalah model demokratis dimana setiap akan mengambil keputusan atau kebijakan selalu melibatkan guru serta terbuka untuk menerima saran, masukan serta kritikan demi pengembangan dan kemajuan lembaga dalam hal ini madrasah yang dipimpinnya.

2. Berdasarkan kategorisasi diperoleh data bahwa tidak terdapat subjek $(0 \%)$ yang memiliki tingkat kinerja rendah, terdapat subjek dengan tingkat kinerja sedang dengan persentase $20 \%$, dan $80 \%$ yang memiliki tingkat kinerja sangat baik. Sedangkan berdasarkan kategorisasi untuk variabel disiplin diperoleh data bahwa tidak 
terdapat subjek (0\%) yang memiliki tingkat disiplin rendah, terdapat subjek dengan tingkat disiplin sedang dengan persentase $30 \%$, dan $70 \%$ yang memiliki tingkat disiplin tinggi. Hal ini berarti skor tingkat disiplin pada objek penelitian dikategorikan tinggi.

3. Berdasarkan hasil analisis data yang dilakukan, maka nilai $\mathrm{F}$ 123,08, signifikansi 0,000dan nilai r square menunjukkan 0,53 artinya bahwa pengaruh model kepemimpinan kepala madarasah terhadap tingkat kinerja dan disiplin guru di Madrasah Aliyah Pondok Pesantren KH. Ahmad Dahlan Muhammadiyah ErengEreng Kabupaten Bantaeng memiliki pengaruh sebesar $53 \%$.

\section{DAFTAR PUSTAKA}

Sulistyorini.Hubungan antara Keterampilan Manajerial Kepala Sekolah dan Iklim Organisasi dengan Kinerja Guru. Jakarta: Raja Grafindo Persada, 2001.

Soegeng, Prijodarminto. Disiplin Kiat Menuju Sukses. Cet. I; Jakarta: Pradnya Paramita. 1994.

Rohiat, Manajemen Sekolah; Teori Dasar dan Praktik, Bandung: Rafika Aditama, 2009.

Soewadji Lazaruth. Kepala Sekolah dan Tanggung Jawabnya. Yogyakarta: Kanisius, 1994. 